Jonathan Koestlé-Cate

Goldsmiths, University of London

\title{
Singularity and specificity: Writing on art
}

\begin{abstract}
A given for art writing today is the necessity of contextualization. This assumption is put to the test when the singularity of a work of art is privileged over its specificity. If the latter infers a context-directed situation in which a cultural object, event or situation is determined by the conditions of its appearance in a particular context, and in which it is invariably subject to certain predominant, context-specific models of interpretation, the former denotes a model whereby a cultural object, event or situation creates its own conditions of reception and establishes its own interpretative frameworks. Art writing that works with a model of singularity does not deny the importance of context, but downplays its influence by privileging the agency of the work of art. This becomes problematic for art criticism when the context appears to play more of a determining role than usual. Such a situation is raised whenever contemporary art enters the church, revealing certain refusals and strategies of avoidance within the secular art press.
\end{abstract}

\section{Keywords}

Specificity, singularity, art writing, exhibition value, cult value, contextuality, contemporary art, churches, cathedrals, exhibitions, installation

\section{Introduction}

It has often been observed that writing on art is at best a secondary activity that attempts to put into words what ought always to be experienced first-hand. As such, it remains an inadequate and vicarious substitute for the thing itself. A number of writers in more recent years have sought to acknowledge and thereby attend to this problem, writing with, rather than on, art. In part, this 'writing with' entails the necessity to deal very specifically with the actual contextual and material conditions, the specificity, if you like, of works of art. This principle might seem obvious, yet, to use a somewhat hackneyed phrase, it is typically more honoured in the breach than the observance. For example, a characteristic complaint of art critic Matthew Collings is that 'all art writing' is, as he puts it, 'maddening', its principal crime being that it is 'contemptuous of reality' (2005: 27). Part of that contemptuousness is its failure to respect or respond to the particular circumstances in which an art object is encountered, an observation that is exacerbated when writing about site-specific installations, that most contextual of phenomena. Contempt for the work of art or, better said, the art event is a concern that motivates numerous writers on art today anxious to rehabilitate the work of art to its conditions of reception. Take Simon O'Sullivan's not untypical call for a heuristic rather than hermeneutic approach to art, in which the emphasis is on the thinking of, and writing on, specific artworks, by which he infers 'attending to the specificity of an art work, and the specificity of the milieu in which the art object operates' (2001: 130). As a Deleuzian O'Sullivan is clearly motivated by the imperative to ask what an artwork does rather than what it means, thereby advocating an exploratory rather than interpretative framework for art history or criticism.

His colleague in the Visual Cultures Department of Goldsmiths College, Irit Rogoff, made a comparable demand, particularly germane to the question in hand, in a round-table debate on art criticism led by James Elkins as part of his Art Seminar Series. In her 
contributed essay, acting as a prompt for the round-table discussion, she develops a rather different approach to the matter of 'specificity', contrasting it with 'singularity' as a means of assessing the focus of cultural critique (Rogoff 2008: 102). By the former she infers a context-directed situation (i.e. 'specific to one particular location') in which a cultural object, event or situation is determined by the conditions of its appearance in a particular context (historical, geographical, cultural, social and so on), and in which it is invariably subject to certain predominant, context-specific models of interpretation. The latter denotes a model whereby a cultural object, event or situation creates its own conditions of production and reception (i.e. 'singular to a logic of its own organization') and establishes its own interpretative frameworks. Once again Deleuze is the inspiration here, notably his view that 'matter' should be seen as 'self-organizing' instead of simply 'filling up previously structured organizing principles' (Rogoff 2008: 105). ${ }^{1}$ For Rogoff perhaps the most crucial disorganizing factor in this shift from specificity to singularity is the role of the viewer. The by-now-familiar move that she instates is to divert our attention away from the historical and cultural specifics of the object of study, and onto the historical and cultural specifics of the one doing the studying: the singular viewing or writing subject.

\section{Singularity vs specificity}

In the field of what has come to be known as 'visual culture' there has been a move in recent years from an art criticism based on the perspective of the disinterested viewer to a more critical engagement that might be more concerned with acting or agency. Rogoff has been one of the prime movers in this field, charting a subtle shift in art writing from a position of criticism to one of critique and lately to something she names, not without some misgivings at the awkwardness of the term, 'criticality', arguing that the latter implies a far greater degree of interaction or participation on the part of the viewer, building on the supposition that a purely objective standpoint is never possible - one is always embedded in one's cultural context with all the limitations of viewpoint this implies. As others have argued (see, for example, Gavin Butt's introduction to his After Criticism), this is precisely the experience of the cultural critic or writer on art, unable to obtain an objective exteriority to the work in question, since he or she is, as Butt puts it, 'always already imbricated in the warp and weft of the cultural text' (2005: 3). As we can see, the singularity implicit in Rogoff's brand of criticality is a more theoretically developed form of specificity, written from the contextual perspective of the critical agent, rather than that of the work itself. However, in effect, Rogoff's emphasis on the role of the observer brings both modes into conjunction, appearing to act as some kind of rapprochement.

Yet another way of reading this difference in specificity and singularity is to apply it directly to the relationship of a work of art and its context. If, then, specificity infers a context-directed situation, wherein an artwork accommodates itself to the specifics of a particular place (as in site-specific work), singularity denotes an art-directed situation, whereby the context accommodates itself to the work of art. This latter approach follows Mieke Bal's definition of 'art writing' as a mode of criticism that 'puts the art first' (cited in Rendell 2010: 1). At the risk of reading more into Rogoff's distinction of the two than she may have intended, the latter might then be far preferable by dint of the dynamic potential it grants to the work of art, where the former threatens to stifle, or at the very least limit, its potential. This dynamic plays out most clearly in the genre of installation art.

As we are aware, all installation art relies upon a specific relationship with its context. Essentially, it refers to the recognition that 'site' describes not only the place of the artwork 
but its mode of being: it is sited. Installations are not spatially autonomous art objects, but are in fact inseparable from their environment, sometimes intrinsically so, as in a site-specific installation whose content specifically reflects upon its institutional environment or whose form is shaped by its spatial environment (such that to remove it or relocate it is to destroy it, the most famous testament to this scenario being, of course, the legal wrangles over Richard Serra's Tilted $A r c)$. Other works are site-adaptable, such that their nature as integrally related to their environment can be repeated elsewhere, even if in each case the objectcontext relationship is unique to each appearance (Antony Gormley's various Fields are a prime example). In other words, some installations are particular to a site and cannot travel; others change and adapt according to the site of their installation. Perhaps the most significant factor in installation art is the spatio-temporal relation it establishes with the viewer, for whom the place of viewing is inseparable from the experience of viewing. Installation requires a space to be inhabited, at least temporarily, rather than presenting an object to be looked at (Stallabrass 2004: 26). As a consequence, installation art is often orientated around the production of a subject of, or for, the work. As Claire Bishop concedes, all art needs a subject, but installation art changes the spatial and temporal requisites of that subject. Distance from the work is virtually eliminated, the time of viewing is extended such that the work cannot be experienced all at once but is transitive, and the space through which the subject moves is itself part of the medium of the work, resulting in a 'mutual imbrication' of subject, object and context (Bishop 2005: 128). This has consequences for interpretation. Meaning is no longer assumed to be embedded in the work of art, merely awaiting the discerning viewer to access it, but arises instead from the encounter between spectator, artwork and location (Oliveira et al. 1994: 13). There is no one fixed point of view, each object-subject relation radically contextualized and subjective, disavowing one single 'theological' meaning, as Barthes might have put it. Context thus becomes the subject matter, rather than merely the setting of the work, reflecting back upon the institution itself and/or the subjects who inhabit it. This does not necessarily imply that the art object is subsumed into its environment, subservient to its host as the bearer of meaning; it is more typically the case that a mutual relation of exchange between work and space is generated, reflecting upon both. Context becomes, in a sense, an accomplice in the production of meaning (Rosenthal 2003: 27).

\section{The art world and the church}

Though it might appear indubitably the case that context these days provides the framework for all discussions of and writing about art, I want to argue that in certain circumstances the desire of cultural commentators to preserve the singularity of the work of art (to put art first) overshadows, or rather displaces, its contextual specificity. Nowhere is this more apparent than in the highly contested realm of art for the church. One of the questions my work considers is the extent to which contemporary art, especially that which bears no obvious religious content nor employs any conventional religious form, is able to enforce its own internal imperatives upon an ecclesiastical space, or, conversely, is obliged to bend to the constraints imposed upon it by that space. This is not our concern here; nevertheless it impinges directly upon the question of writing. What happens when we relocate our discussion from the operations of the work of art itself to those of its critique? As a writer on art whose principal object of interest is contemporary art sited in active churches and cathedrals, the question of context is intrinsic to the object of study, yet it is astonishing how frequently that context is ignored by art criticism. All too often what one discovers is that 
the desire to preserve the singularity of the work of art effaces all, or almost all, reference to its specificity, almost to the point of resurrecting the old trope of autonomy analysed so incisively by Brian O'Doherty, exemplified by the spurious neutrality of the white cube space in which 'art is free [...] to take on its own life' (1986: 15). Though it would, I believe, be unjust to level such a charge at Rogoff, the implications of her affirmation of singularity over specificity could be construed as heralding a recrudescence of an idea thought to have disappeared with the passing of modernity.

A significant aspect of this desire is what we might call the refusals of the secular art world to engage with any religiously inflected discourse in any serious way, unless it treats religion with irony, hostility or scepticism. Frank admissions of sincere belief on the part of an artist are enough to place him or her beyond the pale, banished from serious consideration. For Ena Giurescu Heller, director of New York's Museum of Biblical Art, and a prominent figure writing within the contested field of art and religion, an enforced gap separates the two worlds of art and religion, whatever their common roots, such that little in the way of interaction or dialogue is possible between them. However, on a more optimistic note, she does see signs of change:

Significant efforts have been made in recent years to create a dialogue between art and religious institutions, and between the two fields of inquiry. (Heller 2004: 8)

It must be said that this dialogue tends to go in one direction. It is true that, as she goes on to state, the number of exhibitions with religious themes has dramatically increased, not only in America but in Britain too, and proven to be massively popular (The National Gallery's 'Seeing Salvation' is a case in point), but as her last point implies, whilst the church has enthusiastically embraced the use of contemporary art in its spaces, you would hardly know it from the deafening silence of the art world on this issue. The other side to the kind of dialogue envisaged by Heller was the focus of another of Elkins' aforementioned art seminars, held at the Art Institute of Chicago in 2007 and documented in Re-Enchantment (2009). This debate adds particular grist to our mill, since its very claim to redress 'the nearabsence of religion from contemporary discourse on art' (2009: i) was predicated on the perceived reluctance of the art world to seriously engage with religion's relationship to the western art scene of today except within certain narrow parameters. It is worthwhile dwelling on this debate since its stated aim was precisely to augment the kind of critical response I claim is almost entirely absent from the serious art press. And yet, contrary to Heller's conviction that attitudes are changing, what was striking about the seminar was the degree to which a certain ingrained bias continued to characterize perceptions of the relation between the worlds of art and the church. Indeed, a common assessment of those invited to respond to the seminar after the event testifies to a lack of genuine commitment to the seminar's objectives. Throughout the debate, art and religion are held to be polar categories, in many respects upholding the opinion still held by many who declare the gulf between art and faith to be unbridgeable in the contemporary period. As one contributor put it,

Far from being a conversation about contemporary art and religion - or even about the activity of theorising contemporary art and religion - it is instead a conversation that illuminates a chasm between the assembly and the object of study. (Sally M. Promey, cited in Elkins and Morgan 2009: 223) 
The presence of contemporary art within churches and cathedrals creates anxiety for some, uncomfortable with art's sacrilegious potential, but what the seminar made clear was the degree to which this concern can be inversed, since it exposes a comparable anxiety within the contemporary art world for any forms of cultural production that operate under the sign of religion. This could not be clearer from the reaction of two prominent art critics, Michael Fried and T. J. Clark, who were both invited to the seminar but declined on the grounds that it would be too 'painful' to participate in a discussion linking religion and art in any positive manner. In an age of intertextuality and interdisciplinarity, when it comes to the church, all the old fears of contamination resurface. Whether it is the rise of religious fundamentalism or the stridency of the new atheists, a surprising degree of polar thinking works hard to keep art and culture separate from the church. Where those in favour of such collaborations rightly or wrongly describe cathedrals as an 'unrivalled milieu' for art (Lambirth 1999: 29), others are far more inclined to see the negative impact of so ideologically charged a space. A typical concern, for example, voiced by critic Simon Morley, is the risk of 'over-determining the way in which the viewer will "read" the work through placing it in such a charged context' (1998: 51). Put another way, the negative perception of such environments is that the work of art will be entirely subsumed into the specificity of its context such that all singularity is lost. ${ }^{2}$ Nevertheless, the example of modern and contemporary art produced for, or introduced into, the church so far belies the pessimism of the Chicago symposium's conclusions. Amongst artists whose works can be found in ecclesiastical spaces, we find those who declare themselves to be specifically Christian or confessional artists, religiously or spiritually motivated artists, non-believing artists, atheistic artists and even artists hostile to the church. Amongst works of art found in the church we can name those that are explicitly Christian, specifically liturgical, implicitly religious, vaguely spiritual or mystical, critical of religion, or apparently lacking any religious aspirations at all. From high art to popular religious images, a substantial continuum is apparent.

Why is it then that, as Dan Fox, senior editor of Frieze, put it in an editorial for a special issue dedicated to religion and spirituality, 'it's OK for artists to be "spiritual" in some vague, New Agey sort of way, but "not religious" (2010: 15), or why is it that making art about religion is perfectly acceptable, even welcome, but religious art is not? In an article for Modern Painters, Tyler Green puts it even more bluntly, his declared aim being to examine the question 'does the art world hate religion?' (2011). It might appear that in posing questions like these, both critics are in fact initiating precisely the kind of dialogue I claim hardly exists. To some extent this is true: every now and then art journals have attempted a foray into the hazardous no-man's-land separating the worlds of contemporary art and the church. Yet beyond Fox's editorial comments, venture further in and the journal offers little that extends the range of the dialogue between art and religion. Even more telling is Green's assumption that little exists in the way of scholarly exhibitions that feature contemporary artists examining religion (2011: 30). The only curator or critic he could cite who came close was James Elkins. Like others working in this area, I was rather taken aback by the writer's evident ignorance of an extensive and thriving field of activity. Numerous scholarly exhibitions and their accompanying catalogues and debates could be cited that handsomely fulfil Green's criteria, each exploring various facets of religion and the response of modern artists to it (where he claimed to have found none). What Green's article makes clear is that such crossovers between the worlds of art and religion are generally under-reported and frequently ignored by the secular art press.

A different picture emerges if one takes even a cursory glance at what is happening in the church. Particularly active in drawing together contemporary artists and religious 
questions is the Church of England, whose numerous exhibitions in, and commissions for, churches and cathedrals has led one recent publication to declare that we are witnessing 'something of a renaissance of commissioned art for churches and cathedrals', alongside a profusion of temporary projects (Moffatt and Daly 2010: 7). Most notably, the tendency has not been to invite believing artists but rather contemporary artists of the highest calibre who tend on the whole not to profess any kind of Christian faith. The tensions that arise from these meetings of secular and religious culture are frequently played out through debate and the to-and-fro of scholarly response, producing a considerable body of literature, especially since the 1990s, on the relationship of contemporary art and religion, from writers like Elkins but many others besides.

Let me conclude by focusing on two examples of the kind of work I have in mind, both of which reveal in different ways the tensions, complicities and strategic manoeuvring that arise in art writing when a major artist's work is temporarily installed in, or permanently created for, the church.

\section{Doris Salcedo's Untitled in Liverpool's Anglican Cathedral}

Let us begin with Doris Salcedo's installation for Liverpool's Anglican Cathedral in 1999. Though ostensibly curated as part of the first Liverpool Biennial, which saw contemporary works of art placed throughout the city, Salcedo's contribution far exceeded these parameters, initiating an effective and sensitive engagement with the cathedral and producing in effect an unconventional form of ecclesiastically sited art. Employing her signature amalgam of domestic furniture, spliced together to create disquieting and forbidding fusions, and sealed with concrete, a series of sculptures occupied the well of the cathedral's west end for the duration of the Biennial. The disconcerting effect for the visitor or worshipper encountering Salcedo's installation in the cathedral, especially those for whom it came as an unanticipated surprise, was heightened both by the apparent incongruity of the objects on display and through their unsettling customization. The odd conjunction of deracinated household objects (chairs, tables, beds, wardrobes, cabinets) and, in this case, their sacred context deliberately 'foregrounds an out-of-placeness for the work' (Bal 2007: 48). But Salcedo's use of the mundane made uncanny (literally unhomely: unheimlich) is also concerned with the way a certain space is organized or read. In this respect what is interesting to note is how little has been written about the appearance of her work in the cathedral. In Phaidon's monograph on the artist, for example, one finds several full-page photographs of the event, but barely a word in the text. The photographs provide archival documentation of what is presumed to be in effect just one in a series of installations. Lacking in all this is any critical engagement with the particular dynamics generated by their placement in a cathedral, that is, what the work does in such a place compared with its more recent appearance in London's White Cube gallery, for instance. There is a tacit assumption that although the inherent discourses might differ, and the architectural context is grander, a cathedral venue simply administers another kind of exhibition value to the work, a failing common to site-specific practices that Miwon Kwon calls 'undifferentiated serialisation' (2002: 166). But if we take heed of our earlier positing of the specificity of the work of art, of an art that is put to work within a specific context, then the particularities of its location become imperative.

The reference to 'exhibition value' above introduces a further clue to the disparity of specificity and singularity, one that has proven of value to my research when considering works like Salcedo's and which may be gleaned from Walter Benjamin's differentiation of 'cult value' and 'exhibition value', discussed in his famous essay on the reproducibility of art 
(1999). As you may recall, in Benjamin's schema the former ties an object to the imperatives of ritual, whereas the latter signifies its detachment from auratic values, thereby extending its 'possible futures' in the modern world. Works of art in cathedrals and churches walk a tenuous line between 'cult value' and 'exhibition value', that is, their location within a liturgically focused context, in which they play a subservient role, and their exposure to the public gaze, a larger culture and the variable conditions of reception, in which they play a more dominant role. If ecclesiastically sited art is distanced from the primary functions of its religious context, as something over and above the work itself, its contextual engagement remains relatively shallow. If its ties are too close to its context, it ceases to be a work of art as such at all, becoming subservient to the functions of the church. In this scenario, 'specificity' entirely overshadows the artwork's 'singularity'. In many respects, the argument presented here is an attempt to hold both possibilities in hand simultaneously when writing on (or with) art. Unfortunately, exhibition value can be an unhelpful term when considering the place of art within the church. It goes beyond Benjamin's meaning perhaps, but one of the issues for art in ecclesiastical spaces, compared to the art museum, is how to avoid neglecting the specific context and treating the space in purely exhibitionistic terms. In other words, a vital relation between the work and its context is lost to the value of the context as a grand backdrop for the works themselves. In such scenarios, exhibition value gains such prominence that cult value diminishes to zero. As Paul Bayley, of Art and Christianity Enquiry, says, sacred spaces can never be treated simply as a location for art, but must be respected as an active element of whatever work is on display (2007: 9). He goes on to warn that the increasing prevalence of contemporary art exhibitions in churches and cathedrals brings with it its own problems:

The artist and curator can fall victim to the evocative spell of a place and simply feed off the gravitas that the space brings to their work. There are also the constant needs of the heritage and cultural industry and, dare I say it, those who run our cathedrals, to produce an insatiable demand for spectacle: art can become a cheap, expected and unchallenging tick on the tourist trail after postcards from the gift shop and before cake and coffee in the teashop. Both sides should enter into this dialogue with caution and my feeling is that the more site and place is central to that dialogue the less chance we all have of making mistakes. (Bayley 2007: 10)

Although not a mistake as such, one reviewer of the Liverpool Biennial felt that the grandiosity of the cathedral venue had palpably diminished the politically focused 'emotional charge' of Salcedo's sculptures (Giolla Léith 1999: 158). It was, he said, a bold 'curatorial gamble' that had not quite paid off. Giolla Léith's judgement was prompted by the fact that writers on Salcedo tend to focus on the political attention her work brings to the human stories caught up in its various networks of meaning, for which her work provides a form of witness. In his view, this was attenuated by its ecclesiastical location. His recourse to the singularity of the work led to a failure of vision indeed, considering the social imperatives of the church. ${ }^{3}$ More pertinently, it gave no consideration to the interpretative possibilities engendered by the specificity of the location itself. In the environment of the Anglican Cathedral, though her installation escaped both the limitations of its exhibition or spectacle value and its subsumption into purely cultic value, it did so in favour of interlocking networks of value: aesthetic, religious, liturgical and political.

It is the lack of such observations, through conscious omission or perhaps more typically through uninformed oversight, that distinguishes art writing on events like these. All 
credit to Julian Stallabrass, then, who in a few brief comments on the installation underlines the important conjunction of site and work that governs any interpretative response (2004: 29-31), even if he does not expand upon this possibility. Far more common is the approach disclosed by Mieke Bal's usually conscientious critique of Salcedo's art. In her recently published monograph on Salcedo it is telling that all evidence of the cathedral installation is reduced to two minor references, chiefly in order to discuss one of the particular pieces included (putting, as her own definition of art writing insists, the art first). Yet even in this brief mention she manages to commit a glaring error, significantly misrepresenting the work and underlining the lack of attention paid to the specifics of the event. Bal claims that the sculpture stood in front of the steps to the altar, thereby 'visually blocking one's ascent' to the focal point of the cathedral (2010: 172). In point of fact, the works were installed at the opposite end of the cathedral to the high altar, the steps of Bal's text leading to the north aisle exit, thus necessitating a rather different reading. This faux pas could be dismissed as simply an unfortunate mistake, a lack of critical attention to the specific conditions of an installation, but equally it could be seen as symptomatic of an art writing that remains stubbornly outside its object of study when criticality calls for an ever greater degree of being inside and close to the object of study, a failing exacerbated whenever art enters the church. ${ }^{4}$

\section{Gerhard Richter's Domfenster for Cologne Cathedral}

The same may be said of the critical response to Richter's Domfenster, the stained-glass window he created for Cologne Cathedral in 2007. The two publications on Richter that deal extensively with this commission neglect almost entirely the specifics of its ecclesiastical setting as a religious space, focusing solely on the particularities of its material and ambient properties. Amongst secular writers, only Benjamin Buchloh, the critic most closely associated with Richter, was willing to confront the religious factor, and then only from a defensive position that sought to distance the work from its context. On this occasion there had been considerable publicity surrounding the commission, principally because it aroused the ire of Cologne's Archbishop, Cardinal Meisner. Richter's pixellated window composed of thousands of randomly selected squares of colour, though defended by the cathedral's chaplaincy, was decried by Meisner in unequivocal terms, disturbed not by its abstraction as such, but by the computer-generated arbitrariness of the abstraction. ${ }^{5}$ The ins and outs of this media row are not especially important to the arguments presented here. Of greater import is the response of the arts press, and in this respect Buchloh's defence of Richter's window in the pages of Arfforum may perhaps be taken as representative. Ironically, despite Buchloh's approbation, some of his comments expose his own rather blinkered views. He wonders, for example, to what extent the art object should be decontextualized, noting with disapproval that at its inauguration the window could not be separated from the event (Buchloh 2007: 306). It is not clear exactly what he means by this, but the impression given is that he feels it should be treated in its own right as a work of art, differentiated from its context. For an artwork of this kind this is a rather extraordinary proposition. In many respects Buchloh's reservations typify the art world's reaction to art in churches: the fear that the sacred context threatens to pollute the object of art with an unwarranted religiosity. ${ }^{6}$ Later, when Buchloh intimates that Richter flies 'dangerously close to a retour à l'origine in religious rituals and sanctity that very few artists would dare to approach' (2007: 308), it is interesting to note how threatened he is by that prospect, even to the extent of wondering whether it signifies for Richter a departure from, even opposition to, an Enlightenment- 
directed project of cultural modernism and secularization. His commentary is almost entirely cast in negative terms:

Thus, the final question to be posed is whether these turns to tradition [Buchloh refers to new windows by Lüpertz and Polke as well as Richter] are just personal aberrations, opportunistic deliveries, or whether these manifest denials of the Enlightenment project of the artistic critique of colour constitute in fact an actual desire for a return to the folds of the spiritual, the religious, and the transcendental as immutable conditions of experience that have to be remobilised in the present with more urgency than at any other time during the past fifty years of art production. (Buchloh 2007: 308)

Buchloh's evident suspicion of this remobilization reflects an attitude typical of the current artistic climate in which contemporary art about religion, or art that flirts with notions of the spiritual or transcendent, is perfectly acceptable where sincere religious art is not. If, as Buchloh asserts, Richter's window 'proved that the "merely decorative" is a rather invested, coded, and embattled field indeed' (2007: 306), his own reluctance to confront the distinctly religious context of its ecclesiastical setting in anything other than defensive terms exposes an equally embattled arena for art. Dorothée Brill redresses the balance somewhat in her essay for the catalogue to Panorama, Tate Modern's 2011 retrospective of Richter's career, in which she acknowledges the justifiable theological imperative for critical responses to the window. After all, she notes, whatever other visual analogies the work evokes, interpretations are inevitably complicated by the viewer's awareness of the space as a church and the window's artistic context as Christian iconography from which, despite Buchloh's hopes to the contrary, meaning remains inseparable (2011: 252).

Richter himself is rather more humble in his description of the window than many of his commentators, recognizing the significance of the building and all that it represents, for which his window provides a beautifully rendered complement, even to the extent that he is prepared to say that it may not even be art as such (2009: 525), a comment that must strike the art world as a kind of betrayal of the work's singularity, or capitulation to context, but equally reveals Richter's willingness, against the grain of his critics, to attribute 'cult value' to his work. Whether or not this degree of reflexivity informed Richter's aesthetic choices, his comments give some credence to the idea that the specificity rather than singularity of the work was uppermost in his mind.

\section{Conclusion}

The point being made is that the art press consistently fails to take seriously either art that takes place in religious contexts or art that deals in any serious way with religion, other than to criticize or parody it, to the extent that it discounts its very existence (Green's article is not untypical in this respect, lack of awareness assuming lack of existence). No less a doyen of the art world than Rosalind Krauss has decreed that 'we find it indescribably embarrassing to mention art and spirit in the same sentence' (1979: 54 original emphasis). This follows her assertion of an 'absolute rift' between sacred and secular, which forces 'the modern artist' to choose one route or the other, but not both. ${ }^{7}$ Contrary to this dictum, 30 years on, what is fascinating today is the number of ostensibly non-confessional artists willing to produce work for the church seemingly without irony or any sense of incongruity or inappropriateness, to the incomprehension and horror of those like Krauss, or her October 
colleague, Buchloh, for whom a maintenance of that 'absolute rift' continues to inform their hermeneutical framework. Although many of those involved with ecclesiastical art today, whether Christian believers or not, would almost certainly disagree with Krauss on this last point, it remains a fact that many within the art world do have a problem with bringing 'art' and 'spirit' into the same room, or discussing them on equal terms. Fried and Clark's invitation to participate in a forum on art and religion was declined on more or less the grounds that Krauss describes. The research in which I am engaged has attempted to rectify the situation by drawing greater attention to those works that merit attention or would benefit from a different focus of attention than they usually receive. Not, I should add, out of any evangelistic fervour, but rather out of a sense of the possibilities and alternatives this refocusing presents to the art world. Nor is it in order to discount the importance of the singularity of the work of art, but rather to reinstate a certain specificity that it is all too frequently denied or of which art in religious contexts is habitually purged.

\section{References}

Bal, M. (2007), 'Earth moves: The aesthetics of the cut', in D. Salcedo (ed.), Shibboleth, London: Tate Publishing, pp. 41-63. (2010), Of What One Cannot Speak: Doris Salcedo's Political Art, Chicago and London: University of Chicago Press.

Basualdo, C., Princenthal, N. and Huyssen, A. (2000), Doris Salcedo, London: Phaidon.

Bayley, P. (2007), 'Exhibition review: Light', Art and Christianity, 51 (July), pp. 9-10.

Benjamin, W. (1999), 'The work of art in the age of mechanical reproduction', in H. Arendt (ed.), Illuminations, London: Pimlico, pp. 211-44.

Bishop, C. (2005), Installation Art: A Critical History, London: Tate Gallery.

Brill, D. (2011), 'That's as far as it goes', in M. Godfrey and N. Serota (eds), Gerhard Richter: Panorama, London: Tate Publishing, pp. 245-54.

Buchloh, B. (2007), 'Gerhard Richter: Cologne Cathedral', Artforum, 46:4, pp. 306-09, 376. (2008), 'The diagram and the colour chip: Gerhard Richter's 4900 Colours', in M. Larner, R. Morrill and S. Phillips (eds), Gerbard Richter: 4900 Colours, Ostfildern: Hatje Cantz Verlag, pp. 61-71.

Butt, G. (2005), 'Introduction: The paradoxes of criticism', in G. Butt (ed.), After Criticism: New Responses to Art and Performance, Malden, MA: Blackwell, pp. 1-19.

Collings, M. (2005), 'Diary', Modern Painters, April, pp. 24-27.

Elkins, J. and Morgan, D. (eds) (2009), Re-Enchantment, New York and London: Routledge.

Fox, D. (2010), 'Believe it or not: Religion versus spirituality in contemporary art', Frieze, 135 (Nov-Dec), p. 15.

Giolla Léith, C. M. (1999), 'Exhibition review: Liverpool Biennial of Contemporary Art', Artforum, 38:4, p. 158.

Green, T. (2011), 'Without a prayer: Does the art world hate religion?', Modern Painters, 23:3, April, pp. 28-30.

Heller, E. G. (ed.) (2004), Reluctant Partners: Art and Religion in Dialogue, New York: Museum of Biblical Art.

Krauss, R. (1979), 'Grids', October, 9 (Summer), pp. 50-64.

Kwon, M. (2002), One Place After Another: Site-Specific Art and Locational Identity, Cambridge, MA: The MIT Press. 
Lambirth, A. (1999), 'Some thoughts on art in religious places', in A. Ratuszniak and N. Webb (eds), The Shape of the Century: 100 Years of Sculpture in Britain, Salisbury: Salisbury Festival, pp. 25-30.

Liverpool Biennial of Contemporary Art (1999), Trace: 1st Liverpool Biennial of Contemporary Art, Liverpool: Liverpool Biennial of Contemporary Art in association with Tate Gallery.

Mennekes, F. (2008), 'Lichtblicke in Köln' [Glimpses of Light in Cologne], Stimmen der Zeit, 226:1, pp. 48-64.

Moffatt, L. and Daly, E. (eds) (2010), Contemporary Art in British Churches, London: Art and Christianity Enquiry.

Morley, S. (1998), 'Holy Alliance', Tate Magazine, 16:Winter, pp. 48-53.

Museum Ludwig and Metropolitankapitel der Hohen Domkirche Köln (eds) (2007), Gerhard Richter: Zufall, Köln: Walter König.

O'Doherty, B. (1986), Inside the White Cube: The Ideology of the Gallery Space, Berkeley, Los Angeles and London: University of California Press.

Oliveira, N. de, Oxley, N. and Petry, M. (eds) (1994), Installation Art, London: Thames \& Hudson.

O'Sullivan, S. (2001), 'The aesthetics of affect: Thinking art beyond representation', Angelaki, 6:3, pp. 125-35.

Rendell, J. (2010), Site-Writing: The Architecture of Art Criticism, London and New York: I. B. Taurus.

Richter, G. (2009), D. Elger and H. U. Obrist (eds), Gerhard Richter: Text: Writings, Interviews and Letters, 1961-2007, London: Thames \& Hudson.

Rogoff, I. (2002), 'Studying visual culture', in N. Mirzoeff (ed.), The Visual Culture Reader, London: Routledge, pp. 24-36. (2005), 'Looking away: Participations in visual culture', in G. Butt (ed.), After Criticism: New Responses to Art and Performance, Malden, MA: Blackwell, pp. 117-34. (2008), 'What is a theorist?', in J. Elkins and M. Newman (eds), The State of Art Criticism,

New York and London: Routledge, pp. 97-109

Rosenthal, M. (2003), Understanding Installation Art: From Duchamp to Holzer, Munich, Berlin, London and New York: Prestel.

Rush, M. (1999), New Media in Late 20th-Century Art, London: Thames \& Hudson.

Stallabrass, J. (2004), Art Incorporated: The Story of Contemporary Art, Oxford: Oxford University Press.

\section{Contributor details}

Jonathan Koestlé-Cate is an associate lecturer at Goldsmiths College, University of London. He has studied Fine Art to B.A. level and History of Art to M.A. level and has recently completed a Ph.D. at Goldsmiths College on the subject of contemporary art in ecclesiastical spaces, under the supervision of Professor Howard Caygill.

Contact: Centre for English Language and Academic Writing/Media and Communications Department, Goldsmiths, University of London, Lewisham Way, London SE14 6NW, UK. E-mail: j.koestle-cate@gold.ac.uk

\section{Notes}


${ }^{1}$ Rogoff, like O'Sullivan, places a firm emphasis on 'writing with' or 'to' rather than 'about' art, which alters not only the role of art criticism but its very strategies (see Rogoff 2002).

2 It cannot be denied that churches and cathedrals, though capable of offering an unparalleled aesthetic environment for art, also confront art with a space whose religious history suffuses every nook and cranny, chapel and transept. When art enters a church it encounters a visual heritage that artist and artwork cannot avoid and cannot afford to ignore. Furthermore, just as the church is not simply another cultural venue like any other, neither is it one cultural patron of the arts among many, but rather a patron with particular demands and saddled with singular responsibilities largely absent for other institutions.

${ }^{3}$ For example, Salcedo's political concerns for the dispossessed, the disenfranchised, the distraught and disaffected clearly resonate with the biblical injunction 'to look after orphans and widows in their distress' (James 1:27), defined by the book of James as the mark of a 'pure and faultless' religion.

4 Take as an example this howler from Michael Rush's book on new media for Thames \& Hudson, where he briefly discusses Bill Viola's The Messenger, a significant video installation commissioned specially for Durham Cathedral (1999: 141, 143). Not only does he erroneously claim the film to have been projected onto the ceiling of the cathedral, a supposition belied by the accompanying image of its actual projection against the Great West Door, he even informs us that it was specifically the church dome that provided the setting, a surprise to anyone familiar with the cathedral as one of England's finest examples of Romanesque architecture, furnished with a tower but no dome.

5 In fact, the patterns are not entirely random, with elements doubled and patterns repeated, and certain coloured squares deliberately altered to avoid any misconstrual of image, but the overall effect is of random 'aleatory chromatic constellations', to use Buchloh's terms (2008: 67).

${ }^{6}$ By contrast, the radical Jesuit priest and curator Father Friedhelm Mennekes, always to be relied upon for a contrary position, stressed its inexorable contextualization, and described the window approvingly as a Fremdkörper, a foreign body, within the Gothic space (2008: 55).

${ }^{7}$ Krauss actually goes on to argue that for those artists drawn to the grid as a structuring motif (Agnes Martin is an obvious example, but the gridded structure of Richter's Domfenster is equally relevant), theirs was often an attempt to retain a sense of the spiritual as allegiance to religious belief is increasingly abandoned. 